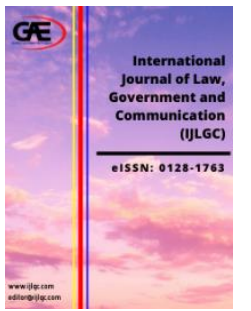

\author{
INTERNATIONAL JOURNAL OF LAW, \\ GOVERNMENT AND COMMUNICATION \\ (IJLGC) \\ www.ijlgc.com
}

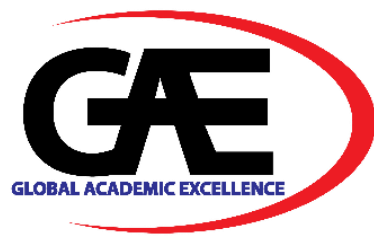

\title{
AWARENESS, ATTITUDE AND PRACTICES TOWARDS COVID-19 AMONG IIUM STUDENTS
}

\author{
Nur Izzati Ariffin ${ }^{1 *}$, Siti Hajar Mohd Badrol' ${ }^{2}$, Siti Aida Aliah Mohd Azlan ${ }^{3}$, Faridah Hussain ${ }^{4}$ \\ 1 Department of Communication, International Islamic University of Malaysia \\ Email: i.ariffin@live.iium.edu.my \\ 2 Department of Communication, International Islamic University of Malaysia \\ Email: h.badrol@live.iium.edu.my \\ 3 Department of Communication, International Islamic University of Malaysia \\ Email: a.aliahzln@gmail.com \\ 4 Faculty of Law, Universiti Teknologi MARA, Malaysia \\ Email: faridah355@uitm.edu.my \\ Corresponding Author
}

Article Info:

Article history:

Received date: 01.03.2021

Revised date: 15.03.2021

Accepted date: 25.04.2021

Published date: 15.06 .2021

\section{To cite this document:}

Ariffin, N. I., Badrol, S. H. M., Azlan, S. A. A. M., \& Hussain, F. (2021). Awareness, Attitude And Practices Towards COVID-19 Among IIUM Students. International Journal of Law, Government and Communication, 6 (24), 01-17.

DOI: $10.35631 /$ IJLGC.624001.

This work is licensed under $\underline{\mathrm{CC} B Y}$ 4.0

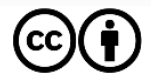

\begin{abstract}
:
The rise of the COVID-19 pandemic has killed more than two million people within a year. The deadly virus brings chaotic problems to every layer of society, including university students. The main goal of this study is to investigate the awareness regarding COVID-19 among International Islamic University of Malaysia (IIUM) students. This study examines the awareness, perception, and involvement of the IIUM community to mitigate the spread of COVID-19 during the scare. A qualitative research design was employed, using an interview method through purposive sampling procedure as the research instrument used for the data collection. A total of eight respondents, including international and local university students, participated in the study. The study adopted the situational theory of publics by Grunig (1966) to guide the study. This study found that IIUM local students have adequate information and awareness regarding COVID-19. However, future efforts should be aimed at enhancing awareness campaigns among the IIUM international students in Malaysia. The findings of the study will have implications on awareness, perception, and behaviour during a virus outbreak.
\end{abstract}

Keywords:

Awareness, Behaviour, Coronavirus, COVID-19, IIUM, Pandemic, Perception.

\section{Introduction}

The world has been set to almost a complete stop this year because of a new pandemic in the coronavirus family, COVID-19. A small microscopic virus has the power to put our lives on Copyright $\odot$ GLOBAL ACADEMIC EXCELLENCE (M) SDN BHD - All rights reserved 


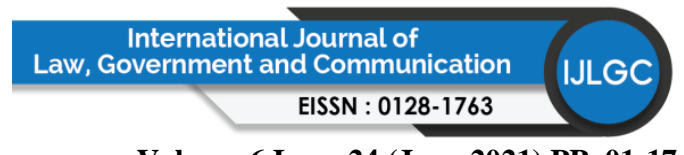

Volume 6 Issue 24 (June 2021) PP. 01-17

DOI 10.35631/IJLGC.624001

hold for months, and it has affected the world's economy to another level. This disease originated from Wuhan, China when the first case was reported in December 2019 (Guo et al., 2020). However, the virus started to spread across the globe in early January 2020 and it has affected many countries which lead to many deaths. At that stage, it has become a pandemic.

The pandemic has caused serious public distress worldwide that has affected public health, the economy travels plan, and educational institutions. Most countries have closed their borders and have proceeded to imply lockdown to mitigate the spread of this virus. Therefore, the economy of the world was almost on pause for the period of lockdown. The symptoms of the infected person include fever, tiredness, dry cough, aches and pains, nasal congestion, runny nose, sore throat, and diarrhoea (Nazario, 2020). The virus travels from person to person by tiny droplets from the nose or mouth through coughs or exhales from an affected person.

COVID-19 is different from other coronaviruses because its rate of infection is much higher. Other coronaviruses such as MERS and SARS are not as highly contagious, and death toll numbers are also much lower compared to COVID-19 (Chai, 2020). Although the virus is highly contagious and can be fatal, experts and health care workers have found that there are many ways to mitigate the virus from spreading and stopping the pandemic. Among the effective ways to mitigate the spread of the virus is to frequently wash our hands and sanitise after having contact with the outside environment, to practise social distancing and not getting too close to other people, and to wear the mask at all times when going outside (Smith, 2020).

Due to the Coronavirus Disease 2019, on 18 March 2020, the Parliament of Malaysia has enacted new law known as the Temporary Measures for Reducing the Impact of Coronavirus Disease 2019 (COVID-19) Act 2020. The law was enacted on temporary measures to reduce the impact of Coronavirus Disease 2019 (COVID-19). As a result, few relevant provisions has been modified such as the Limitation Act 1953, the Sabah Limitation Ordinance, the Sarawak Limitation Ordinance, the Public Authorities Protection Act 1948, the Insolvency Act 1967, the Hire-Purchase Act 1967, the Consumer Protection Act 1999, the Distress Act 1951, the Housing Development (Control and Licensing) Act 1966, the Industrial Relations Act 1967, the Private Employment Agencies Act 1981, the Land Public Transport Act 2010, the Commercial Vehicles Licensing Board Act 1987, the Courts of Judicature Act 1964, the Subordinate Courts Act 1948 and the Subordinate Courts Rules Act 1955. Several known regulations such as no interstate and interdistrict travel, no social gathering, school and universities closures lead to chaotic problems to every layer of society including IIUM student.

COVID-19 has caused serious public distress worldwide that affected the health of the public, economy, education, travel plans, and jobs. Schools and workplaces are being closed due to the seriousness of this crisis. Thus, this study explores awareness, attitude and practices of the IIUM community (local and international) during this worrying time as IIUM is an International Institution with a large number of international students, including students from China. Despite the actions taken by the institution, it is also crucial that the IIUM community (students and staff) itself are well aware of COVID-19.

\section{Problem Statement}

This study explores the awareness, attitude practices related to COVID-19 among students in the institute of higher learning in Malaysia. The possibility of a cluster emerged on the university premise that may cause the institution to become an epicentre for the pandemic. 


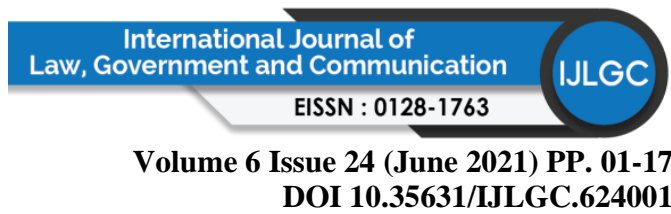

Having a large population such incidents may create chaos besides putting thousands of lives in danger.

In this pandemic, Berlinger (2020) stated that WHO warns the government of all countries and higher authorities to be aware of the coronavirus spread as it will get worse from time to time. The authorities should repeatedly warn its people to keep clean by washing their hands and regularly sanitizing apart from maintaining social and physical distancing. All of this information frequently communicated using various media platforms to empower the public to keep themselves safe from the virus. Similarly, the International Islamic University of Malaysia (IIUM) has also taken preventive measures to ensure the campus is free from viruses. Among preventive measures taken include 10 days of class postponement from 13 February to 23 February 2020 for the Gombak campus even before the enforcement of the Restricted Movement Order (RMO) (Annuar, 2020). IIUM campus then is closed starting from 18 March 2020 until the end of the semester. This scenario has greatly affected the students and lecturers since this is their first time encountering no physical class throughout the semester. Thus, this study seeks to find out the perception, attitude, and practices of IIUM students related to COVID-19 using the Situational Theory of Public in order to ensure that the campus is free from COVID-19.

\section{Research Questions}

1. What is the extent of awareness of the COVID-19 pandemic among the IIUM students?

2. What is the perception towards COVID-19 among the IIUM students?

3. What is the involvement of the IIUM students to mitigate the spread of COVID-19 during the scare?

\section{Research Objectives}

1. To examine the IIUM students' awareness of the COVID-19 pandemic.

2. To understand the perception towards COVIS-19 among the IIUM students.

3. To explore the involvement of the IIUM students to mitigate the spread of COVID-19 during the scare.

\section{Significance of the Study}

This research is exploring awareness, attitude and practices related to COVID-19 among IIUM students. Hence, the outcome of this research might aid the Malaysian Ministry of Health $(\mathrm{MoH})$ to develop and create effective awareness campaigns particularly during the pandemic situation especially in handling the transmission of infectious viruses and surviving pandemic outbreaks in the future. In addition, this study secured insight from international respondents studying in the local university. Besides, the Ministry of Education Malaysia (MoE) might gain benefit from this study as MoE might be able to understand the students`awareness, attitude and practices regarding COVID-19 in Malaysia. By analyzing their experiences and behaviours regarding the pandemic outbreak, it is easier for $\mathrm{MoE}$ to aid the students` needs during a pandemic or create a new policy or guideline regarding their stay on the campus during the outbreak.

For practical implications, this study might contribute to the crisis management team in universities in developing COVID-19 awareness programs for local and international students in IIUM. The findings from the study may also be a guideline for the regulatory body in IIUM 


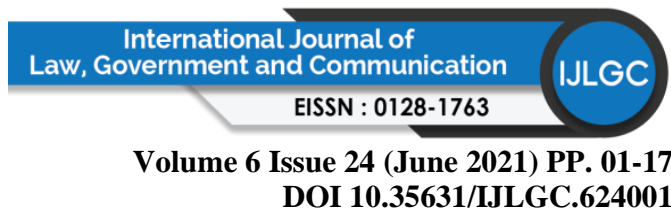

and other universities to formulate policy regarding sharing false information among students about COVID-19. The analysis of the study will also assist future studies, especially in the field of health communication, crisis communication as it provides a deep understanding of the way university students experienced the COVID-19 pandemic.

This study might facilitate academicians in relating pandemic with the Situational Theory of Public. The theory applied in this study helps to understand different type of public and their communication behaviour during the pandemic outbreak. Apart from that, this study also can be used to classify how different types of publics deal with information, and their behaviour varies depending on the amount of information that they have.

\section{Literature Review}

\section{COVID-19 Pandemic}

The World Health Organization (WHO) plays a big role in this ongoing pandemic. According to World Health Organization (2020), coronaviruses are a large family of viruses that may cause illness in animals or humans. The Coronavirus is not a new virus as there is another coronavirus that has long existed. Examples include Middle East Respiratory Syndrome (MERS) and Severe Acute Respiratory Syndrome (SARS). The newest that has surfaced in late 2019 is, of course, the COVID-19.

Among the symptoms of a person that has been infected by the virus are fever, tiredness, dry cough, aches \& pains, nasal congestion, runny nose, sore throat, diarrhoea (WHO, 2020). COVID-19 can be spread from person to person through small droplets from the nose or mouth when an infected person coughs or exhales (WHO, 2020).

\section{COVID-19 in China and Southeast Asia}

Reynolds and Weiss (2020) reported that in China, the disease originally came from a Wuhan seafood market where wild animals including bats and snakes were illegally traded. On $31^{\text {st }}$ December 2019, the WHO China office heard the first report of a previously unknown virus behind several pneumonia cases in Wuhan with a population of over 11 million (Reynolds \& Weiss, 2020). On January $1^{\text {st }}$, 2020, the Wuhan market was closed down for cleaning and sanitation activities although by the time the virus has already infected 80,757 people, killing 3,136 (Reynolds \& Weiss, 2020).

Several countries in Southeast Asia also have identified imported cases of COVID-19 which originated in China. Some Southeast Asian nation which had previously reported few or no case of COVID-19 began to sprout up with numbers of cases as those countries struggle with imported cases and in some instances, human-to-human transmission from those imported cases (World Aware, 2020). As of $11^{\text {th }}$ March 2020, countries from Southeast Asia that have identified confirmed COVID-19 cases are Singapore, Malaysia, Thailand, Indonesia, Cambodia, Philippines, Vietnam and Brunei (Kementerian Kesihatan Malaysia, 2020).

Malaysia is one of the affected countries and became the second most infected country after Singapore in southeast Asia as of $11^{\text {th }}$ March 2020. The COVID-19 outbreak in Malaysia began in the mid of January, where 3 cases had been confirmed by the Public Health Ministry. New Straits Time (2020) reported that all the first 3 cases were imported cases from China which 


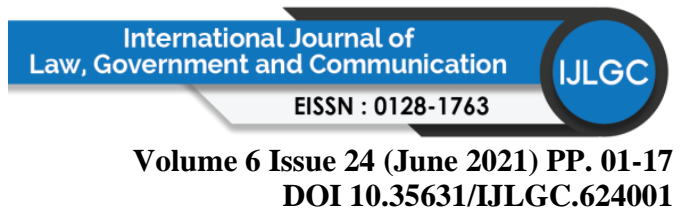

they were in the same group that travelled from Wuhan with Singapore`s first case of COVID19. The number has increased drastically to 129 cases as of $11^{\text {th }}$ March 2020 (Reuter, 2020).

\section{COVID-19 in IIUM}

The International Islamic University of Malaysia is not spared in this health crisis. Having many international students that need to stay on campus since they cannot go back to their home countries has made the university take serious intervention to ensure the university premise is free from COVID-19 infectious disease.

IIUM has decided to take maximum precautionary measures by postponing all classes at the Gombak campus from 12th February to 23rd February 2020 to ensure the maximum standards of safety and wellbeing of the IIUM community (Annuar, 2020). Besides, IIUM also keeps updating precautionary steps on their websites to help students to empower students to be able to protect themselves from the virus. However, every effort by the university or the government needed to be complemented by the students` own awareness. Hence, this study aims to investigate IIUM students' awareness, perception, and involvement to mitigate this deadly virus.

\section{The Situational Theory of Publics}

Grunig (1966) developed a situational theory of publics to explain and predict why some publics are active, and others are passive. Within the stakeholder categories, he notes that situational theory can identify which publics will "communicate actively, passively, or not at all about organizational decisions that affect them" (Grunig, 2005, p. 779)

According to Grunig and Hunt (1984), there are four types of publics which are; nonpublic, latent publics, aware publics, and active public. Nonpublic is the public who do not face the problem, latent publics are the publics who face the problem but do not recognize it as a problem, aware publics is the public who recognize the problem, and active publics are the publics who do something to encounter the problem (Grunig \& Hunt, 1984).

Besides, Schmitz (2012) claims that there are four types of communication behaviour under the situational theory of publics which are; problem-facing behaviour, constrained behaviour, routine behaviour, and fatalistic behaviour. Problem-facing behaviour is the behaviour that has high problem recognition but low constraint recognition, constrained behaviour is the behaviour that has high problem recognition and high constraint recognition, routine behaviour is the behaviour that has low problem recognition and low constraint recognition, and lastly, fatalistic behaviour is the behaviour that has low problem recognition but high constraint recognition (Schmitz, 2012). This study would provide insight into students' communication behavior on campus during the pandemic. This is useful so that effective awareness campaigns for university students are able to be developed and created.

\section{Methodology}

\section{Research Design}

This study applied qualitative research design and International Islamic University Malaysia (IIUM) students are selected in this study. Qualitative method is highly crucial especially if the topic is too complicated to be answered by a yes or no hypothesis (Shuttleworth \& Wilson, 2008), hence, this research design suit the study goals in which to answer the 'how' and 'why' 


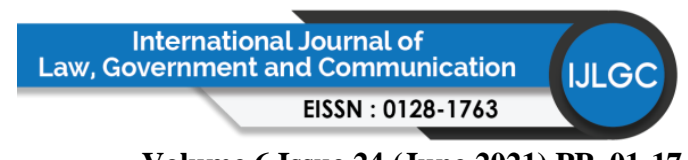

Volume 6 Issue 24 (June 2021) PP. 01-17

DOI 10.35631/IJLGC.624001

questions regarding the knowledge, attitude and behaviour of IIUM students regarding COVID-19. Besides, since this study's analytical objective is centred on describing IIUM students' experiences and beliefs about COVID-19, a qualitative research design is the best method to be adopted since it aids to reach holistic, rich, and nuanced data for the findings (QuestionPro, 2020).

\section{Population and Sampling Procedure}

For this research, IIUM students at the Gombak campus are the target population. This campus is extremely ideal to be selected in this study since there is a huge number of international students studying here, including the students from China, the first country in which COVID19 was first discovered. In view of these considerations, the reasons why this population has been chosen are justified.

Purposive sampling was adopted in this study to reach eight respondents. According to Dudovskiy (2020), purposive sampling is a sampling technique in which scholars use their own judgments on selecting members of the population to participate in the research. Also, purposive sampling is a non-probability sample that is selected based on the characteristics of a population and the objective of the study (Dudovskiy, 2020). Thus, this study chooses the respondents who have the same characteristic, in which all of them come from badly affected nations. The nations selected are Southeast Asia countries and China.

\section{Instrumentation}

For a qualitative interview, the researchers themselves are the main instrument for the collection of the data, and the researchers need to have skills in observing, taking notes, talking to people and conducting the interviews (Atlas, 2020). Hence, these skills have been carefully applied in this research, especially when all the interview sessions are a bit harder since it could not be conducted face-to-face due to the Restriction Movement Order (RMO).

\section{Data Collection}

Researchers contacted three Malaysian students, two Chinese students, two Indonesian students and a Cambodian student, and delivered a brief introduction regarding the research at the beginning of the interview sessions. Six of the respondents are postgraduate students and two of them are undergraduate students studying in IIUM. Due to COVID-19, all respondents are contacted online via the WhatsApp application. The respondents are given options whether they wanted the interview sessions to be conducted via call, video call, or WhatsApp voice notes and chats. Most of the respondents prefer WhatsApp and call as the medium of the interview sessions. The interview sessions via call last about 30 minutes, meanwhile the interview sessions via WhatsApp application take a long time since the respondents choose their own free time to answer the questions. The timeframe of the interview session is from 15 July 2020 until 4 August 2020.

A semi-structured interview is employed as the method of data collection. A semi-structured interview is a meeting in which the interviewer does not strictly follow a formalized list of questions, and the interviewer will ask more open-ended questions, allowing for a discussion with the interviewee rather than a straightforward question-and-answer format (Doyle, 2020). Hence, for the present study, a semi-structured interview is utilized to elicit respondents' beliefs and life experiences encountering COVID-19. The open-ended questions regarding respondents' knowledge, attitude and behaviour regarding the COVID-19 pandemic are asked. 


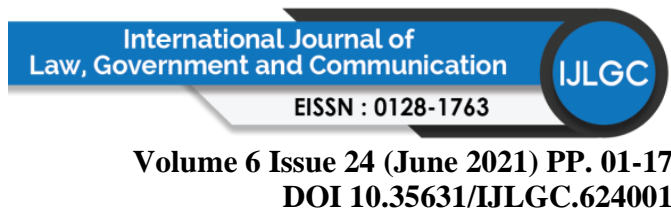

Every interview has a different format, however, the semi-structured format is guided by three main themes, which are; IIUM community awareness on COVID-19 pandemic, the perception towards COVID-19 among the IIUM community, and the involvement of the IIUM community to mitigate the spread of COVID-19 during the scare.

\section{Data Analysis}

The transcript was analyzed using thematic analysis by identifying dominant themes from the data. All interviews were transcribed verbatim, producing 33 pages of a single-spaced document. After transcribing, all of the authors repeatedly reviewed the transcripts to ensure that it is clean and consistent with the audiotapes. The demographic and psychographic details of the respondents are recorded along with the answers.

\section{Findings and Discussion}

Participants of the study offered various and diverse descriptions of their experiences regarding COVID-19. Their opinions and experiences are divided into three main themes that are aligned with the research objectives of this study. The main themes are; IIUM community awareness of the COVID-19 pandemic, the perception towards COVID-19 among the IIUM community, and the involvement of the IIUM community to mitigate the spread of COVID-19 during the scare.

To understand the multiple realities, the findings section also will be divided based on the nationality of the respondents, which are, Chinese and those who are from Southeast Asia countries (Malaysian, Indonesia, and Cambodia). To ease the analysis process, the respondents' nickname will be mentioned. There are three respondents from Malaysia, which are Husna (24 years old), Khairul (32 years old), and Hanisah (24 years old). There are two respondents from Indonesia, namely, Putri (27 years old), and Adel (28 years old), and also a Cambodian, Kreya (28 years old). Lastly, there are two respondents from China in which, however, have the same name; Maryam 1 (19 years old), and Maryam 2 (21 years old).

\section{IIUM Community Awareness on COVID-19 Pandemic}

\section{Knowledge on COVID-19}

\section{Southeast Asian students}

All Southeast students can describe what COVID-19 is, and they have knowledge about the virus. They know that this virus infects and attacks the respiratory system and lung, which cause difficulty in breathing. They also know that this virus is originated from China mainland. One of the Malaysian students explained that this virus could cause death to the people who get infected. Husna (24) described:

"What I know about COVID-19 is COVID-19 is an infectious disease which is, this virus actually is a threat to our respiratory. It will make us hard to breathe and so on, which in the long run can actually cause death." (Husna, Malaysia)

Southeast Asian students also believe and keep their hope up for the vaccine to be found. They believe that this disease will be cured and the vaccine will be found as the scientist are working hard to create the cure for this virus. So, all of them have positive hope that the vaccine will be figured out one day based on the knowledge they have about COVID-19. In addition, Putri (27) 


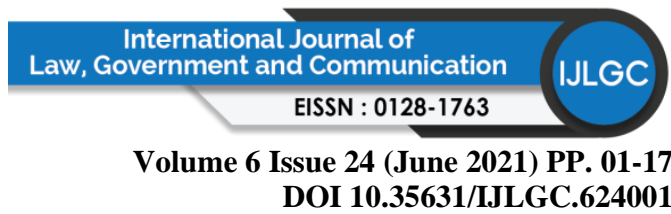

mentions that the disease can be treated because there are already people that have recovered from the disease.

"I believe that this infectious disease can be cured because we can see there is certain country succeed in containing this virus and they have a huge percentage of recovered patients and in Malaysia as well, now you can see that the active case Is decreasing day by day right. So, we can see as well how pharmacies around the world, are spearheading the virus, I mean the vaccine to contain this disease." (Putri, Indonesia)

\section{Chinese Students}

For the Chinese students, they have basic knowledge about COVID-19 in which they know that COVID-19 is a dangerous infectious virus, and it can affect the human lung and respiratory system. The Chinese students also know about the symptoms of COVID-19. Maryam 1 (19) explains:

"The main symptoms (of COVID-19) are cough, breathing difficulty and fever, but there are a few cases where (the infected persons have) no fever, (but they suddenly) die." (Maryam 1, China)

The Chinese students also believe that COVID-19 can be cured since they claimed that the fact is many people in the world are already cured, and the vaccine is already in the experimental stage. Besides, Maryam 1 (19) also believes that herbal medicine could somehow cure COVID19:

"It can be cured because the vaccine is already in the experimental stage, and it was also discovered early on in China that herbal medicine could somehow help with the coronavirus." (Maryam 1, China)

The results indicated that interviewed Southeast Asian and Chinese students have sufficient knowledge of COVID-19. They have knowledge about the virus and how this virus infects and attacks the respiratory system and lung, which cause difficulty in breathing. This is in line with the information provided by the World Health Organization (WHO) through their website as it plays a big role in this ongoing pandemic. WHO provided all the important information on their website for reference to all people across the globe (WHO, 2020). All interviewed students from Southeast Asia and Chine believe that this virus can be cured.

\section{Knowledge of Precautionary Measures to Fight COVID-19}

\section{Southeast Asian Students}

Malaysian students have sufficient knowledge of precautionary steps that need to be taken to fight COVID-19. The main precautionary steps they took are wearing masks, using hand sanitizers, social and physical distancing, avoid from going to crowded places and avoid from bringing high-risk people such as old folks and children from going out to public places. Hanisah (24) explained:

"It is always about the physical distancing meaning that we observe the 1 meter from other people and also sanitizing our hands before we enter any place and move from that place and then washing our hands with the seven steps and avoid ourselves from a place that is occupied with people such as a mall, restaurant without anything 


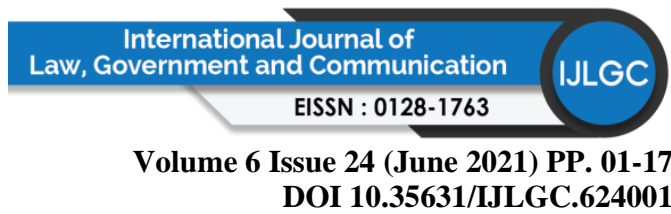

important and urgent that we need to take care of. We also should avoid bringing our kids especially the babies to this kind of place because they are at high risk to be infected by this kind of virus and also old folks and old citizens that is maybe above the '60s, also need to avoid going to those kinds of places." (Hanisah, Malaysia)

However, Kreya (28) said that although he knows what to do to avoid catching the disease, he does not believe that he has sufficient information on it:

"I don't think I have enough information regarding precautionary measures to protect from the virus. What I had known is I must keep wearing a face mask when going out. I also need to frequently clean my hand with soap or hand sanitizers and stay away from the crowd. Next, don't touch my mouth, nose, and eyes by using my fingers rather using my arms." (Kreya, Cambodia)

\section{Chinese Students}

For Chinese students, they believe that they have enough knowledge of the precautionary measures to fight COVID-19. Both of them agree that to prevent COVID-19, facemask and sanitizers are very important to be kept. Maryam 2 (21) claims:

"I think I have enough information things to protect myself. Like I already prepared many mask and medical alcohol and many sanitizers." (Maryam 2, China)

The result showed that Malaysian and Chinese students have sufficient knowledge on precautionary steps that need to be taken to fight COVID-19 such as wearing masks, using hand sanitizers, social and physical distancing, and avoid from going to crowded places. However, Kreya (28) from Cambodia reported that he did not have sufficient knowledge of the precautionary measure. This is in line with the report that stated the Prime Minister of Cambodia did not give any concern on the COVID-19 issue and opposed the people who try to take preventive measures such as wearing a mask (Louis, 2020). This scenario caused their citizens did not get sufficient information on precautionary measures to fight COVID-19.

\section{The Perception Towards COVID-19 Among IIUM Community}

\section{Attitude towards COVID-19}

\section{Southeast Asian Students}

Some of the Southeast Asian students stated that they actively share information regarding COVID-19 on their social media accounts such as Facebook. Husna (24) reported that she did no actively share it, but she did seek the information through Instagram. Khairul (32) claimed that sharing information on social media is extremely important:

"Yes, I have shared all the information about COVID-19 on my social media accounts actively, using Facebook, using WhatsApp, using YouTube, and even e-mail. So yes, for me, the sharing of information on COVID-19 in our social media accounts is very important, extremely important so that we can ensure that all of us know this COVID19 current situation." (Khairul, Malaysia) 


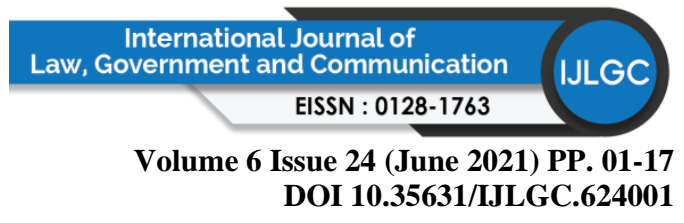

The Southeast Asian students reported that this pandemic had affected their daily routine in many ways. For Adel (28):

"I feel that I'm affected severely in my mental due to the change of my daily practice like from attending physical class to online class, from praying together to praying alone and so on." (Adel, Malaysia)

\section{Chinese Students}

For Chinese students, they have different perception regarding sharing news updates about COVID-19 from social media. One of them believes that it is very important yet the other one believes that it is not important. Maryam 1 (19) says:

"It is very important. Nowadays people rarely watch TV or read newspapers, so all sources of news are through mobile phones. For example, in China, we show daily new diagnoses and deaths on WeChat as well as important updates about the outbreak that can draw the attention of older and younger people at the same time. When they are afraid of an epidemic, they can defend themselves well." (Maryam 1, China)

However, Maryam 2 (21) has a different opinion:

"I think it's not important for me to share the information because I am not a professional, maybe my information is wrong." (Maryam 2, China)

Besides, the Chinese students also express their fear towards COVID-19. Both of them are afraid that the virus will infect their family. Maryam 1 (19) adds that she feels COVID-19 affected her daily routine when she cannot return to her home country. She claimed that she could not buy the flight tickets because the pandemic tickets are limited. For Maryam 1 (19), COVID-19 also affected her daily routine because she is afraid to go out shopping and eating:

"It does affect (me) because I'm afraid to go out shopping and eating and I can't return to my own country because the pandemic tickets are limited." (Maryam 1, China)

The results also indicate that all Southeast Asian and Chinese students reported that COVID19 affected them in their daily life. They are scared to go to public places that have a lot of people, and all of them stated that they would just go out for important purposes such as buying groceries and ensure they are taking all of the precautionary measures before going out. Thus, all of these results support the study from Timsit (2020), COVID-19 issues make people more likely to believe false claims, and probably pessimistic, hostile or threatening attitudes towards those around us. In brief, it can be seen that the study of the attitude towards COVID-19 during this pandemic is important in creating constructive movements and actions to build a safe community and environment from COVID-19.

\section{Opinions Toward the Government and IIUM}

\section{Southeast Asian Students}

All the respondents from Malaysia stated that they are getting sufficient knowledge of COVID19 from the government of Malaysia. All of them stated that the government gives them clear and sufficient information to the public and the government also being successful in managing 


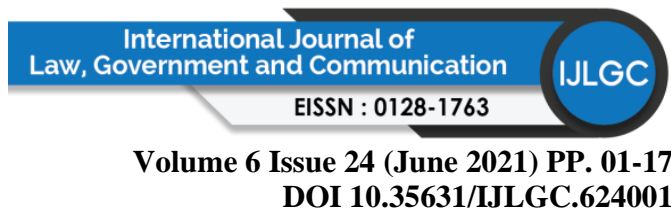

and releasing the information during this pandemic. Husna (24) claimed that the Malaysian government gave very detailed information on COVID-19 and the government keep updating the information daily through the press conference:

"I really do believe that Malaysia government really give clear and very simple information that can be understood by everyone about the information on COVID-19; from how this disease been spread, how long the virus can stay on the surface area like paper, plastic whatsoever. The information is very clear. On the other hand, every day, there was a press conference every single day for about two or three months. They told you on how many new active cases, how many newly found cases, how many it been spread, is it locally spread or is it from outside so that it is very clear on what has been done." (Husna, Malaysia)

Southeast Asian students also think that IIUM has taken the right actions by postponing classes in the second week of the semester last February as precautionary measures to prevent COVID19 from spreading in the IIUM community. Kreya (28) said:

"Yes, I do support the decision of IIUM community in postponing the class in last February because IIUM is the place where people from different areas are coming and having close contact which enables the spread of the virus among students and IIUM staff. So, it's good to postpone physical class during that time." (Kreya, Cambodia)

\section{Chinese Students}

Chinese students have the same perception regarding the China government in which she believed that the China government has already released enough information and has done the proper notification regarding COVID-19. Maryam 1 (19) explains:

"For China, the epidemic came out of Wuhan, and the government may have done the proper notification of the epidemic, but parts of the people were out of control, some of them escaped before Wuhan sealed off the city, and the government promptly reported the situation to the nation." (Maryam 1, China)

Regarding the perception towards IIUM, Chinese students agree that the university did the right thing to postpone the classes and changed the classes to online mode. They perceive that IIUM action is correct because it will protect IIUM students, especially when the face-to-face class will make the students mingle with each other and disregard social distancing. Maryam 1 (19) also believes that the online class should proceed to the next semester:

"This (action) is correct, and even next semester should continue to teach in the same way as online classes because our university has a lot of international students. All people came back from around the world, and the epidemic was not controlled globally. This increases the health risk for everyone. We should respect life." (Maryam 1, China)

Southeast Asian students have a good perception of the precautionary steps that are taken by the Malaysian government to prevent the spread of the COVID-19 outbreak especially when the government decided to set up the lockdown which is called Movement Control Order (MCO) or Restriction Movement Order (RMO) from18 March to 31st August in order to fight COVID-19. All students from Southeast Asia and China think that IIUM has taken the right actions by postponing classes in the second week of the semester last February as precautionary 


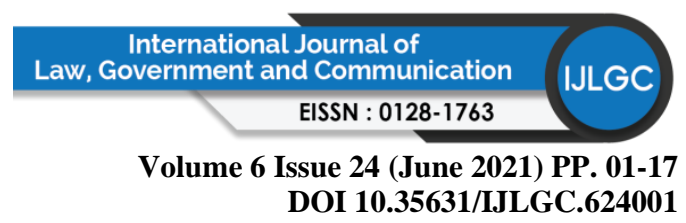

measures to prevent COVID-19 from spreading in the IIUM community. The results support the article from Annuar (2020) that stated IIUM decided to take proactive and maximum precautionary measures by postponing all classes at the Gombak campus from 12 February to 23 February to ensure the maximum standards of safety and wellbeing of the IIUM community.

\section{The Involvement of IIUM Community to Mitigate the Spread Of COVID-19 During the Scare}

\section{Behaviour on Spreading Awareness to The Community}

\section{Southeast Asian Students}

Southeast Asian students have positive behaviour regarding COVID-19. They are aware of the importance of sharing knowledge and information on COVID-19 with their family and friends. Putri (27) stated:

"I usually share it (the information) in my family WhatsApp group as well about the situation here and I also ask them the situation back home because I need to make sure as well if my family is doing well or not there." (Putri, Indonesia)

However, some of them did not share the information regarding COVID-19. Kreya (28) said:

"I don't actively share the information of COVID-19 in my social media account." (Kreya, Cambodia)

Malaysian students are aware of the importance of sharing knowledge and information on COVID-19 with their family and friends. They indicate that other people might not be aware of what is happening and sharing information can help other people such as our family and friends to realize the danger of COVID-19. Hanisah (24) explained:

"Yes, it is important for us to share the news update because maybe some people do not have time to keep themselves updated with this pandemic but the most important thing is that we should only share valid news and from reliable sources" (Hanisah, Malaysia)

Some of the Malaysian students reported that there is no program that aims to prevent COVID19 held in their community. However, Husna (24) stated that even though there is no event held in her community, she will always support any programs related to fighting the virus:

"I am not too sure about the community or any program in the community, but there are none of the programs in my community. But if there is any program held, I would love to support it" (Husna, Malaysia)

Khairul also supports the program that aims to prevent COVID-19 by joining the IIUM Briged Team and volunteering to do and prepare the PPE equipment for the frontliners for like three months:

"I actually have volunteered myself to do the PPE equipment. I have joined the IIUM Briged Team to prepare the PPE for the frontliners, for like three months. And I am 


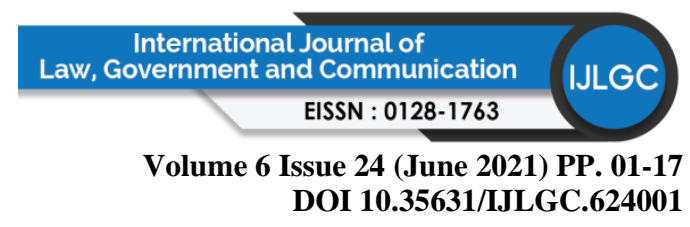

really glad that I have joined the team. Because at least, I can help the frontliners to do the job. At least for me as a student, I can prepare the PPE, the things that they have to wear while dealing with COVID-19 patients." (Khairul, Malaysia)

\section{Chinese Students}

For the Chinese students, they practice different behaviour regarding sharing news updates about COVID-19 that they get from social media. For Maryam 1 (19), she will make sure to use her social media accounts to spread prevention measures to combat COVID-19:

"Yes, I will be making more use of WeChat and Instagram to promote proper prevention measures for my family and friends, as well as where are these newly infected people and the trajectory of the infected people's actions. On Instagram, I'll be dispelling rumours about the outbreak to my friends from other countries." (Maryam 1, China)

However, for Maryam 2 (21), she did not share any information regarding COVID-19 in her social media accounts because she thinks that she is not the right person to share the information:

"I don't share information on social media because I already said, it might be wrong, and I'm not a professional. But sometimes, I will share information with my friend or family. I do ask my friend and my family to wear the mask and prepare medical alcohol because the alcohol can kill the virus." (Maryam 2, China)

Briefly, Southeast Asian students are aware of the importance of sharing knowledge and information on COVID-19 with their family and friends. They indicate that other people might not be aware of what is happening. Meanwhile, Chinese students differ in their behaviour regarding sharing news updates about COVID-19.

\section{Self-precautions against COVID-19}

\section{Southeast Asian Students}

All Southeast Asian students take precautionary steps to prevent themselves from catching the virus. Adel (28) said in her answer:

"My self-precautions are by staying at home, going outside for necessity or some important stuff only. And when I am outside, I keep social distancing and will bring hand sanitizer everywhere." (Adel, Indonesia)

Meanwhile, Putri (27) added that she always takes care of herself by being hygienic and not going to the red zone area:

"In order to prevent me from catching the virus, of course, I have to make sure my selfhygiene and yeah second not going out or rarely and I try to avoid the red zone. That is why until now, I do not take the decision to go back to Indonesia because as we know Indonesia currently in red zone especially in my hometown, Surabaya" (Putri, Indonesia) 


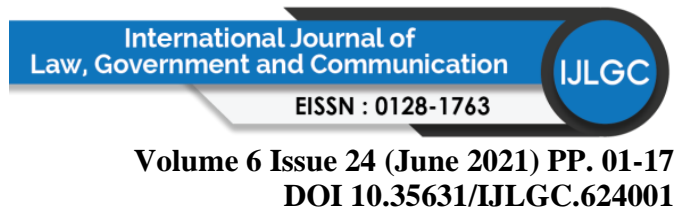

Kreya (28) added that he takes precautionary steps for himself by taking care of his hand hygiene and praying:

"I take some precautionary steps like always cleaning my hand with hand sanitizer, avoid shaking hand with strangers and always making du'a (prayer).” (Kreya, Cambodia)

All Malaysian students take precautionary steps to prevent themselves from catching the virus. Khairul (32) explained the precautionary measure that he takes:

"I will try my best to limit my movement outside of the house. That means I am trying my best to go out less unless I have to do something. I try to avoid the area where there are a lot of people. I also try my best to follow all the instructions given by the government. Meaning to say that, whenever let say I am somehow meet friends outside, I will not shake their hands" (Khairul, Malaysia)

\section{Chinese Students}

Chinese students have different behaviour regarding their self-precautions against COVID-19. Maryam 1 (19) actively seeks information about COVID-19 via official websites; however, Maryam 2 (21) claims that she did not seek the information because she has other things to do and she did not want to waste time.

Besides, for the self-precaution, Maryam 2 (21) says she only practices social distancing and wears a facemask. Maryam 1 (19) did the same preventive measures, but she is a little more careful since she rarely goes out, and even if she did go out, she would disinfect her belongings:

"I rarely go out and hardly ever see my friends. I gather sparingly, wear masks, wash hands frequently, and disinfect purchased items and clothing after returning home." (Maryam 1, China)

To conclude, most Southeast Asian students are actively seeking information on COVID-19 from social media. They seek information from valid sources. Meanwhile, Chinese students have different behaviour regarding their self-precautions against COVID-19.

\section{Conclusion}

This study presented the views of the participants from various nations, including China and Southeast Asia countries like Malaysia, Indonesia, and Cambodia. Most of the participants are postgraduate students, and their age range is from 19 to 32 years old. The findings of the research have addressed all the research questions. The participants have different kinds of knowledge, attitude, and behaviour regarding COVID-19. Nevertheless, the data become saturated when no new data emerged from the interviewees. All of them somehow have the basic knowledge about what is COVID-19, how it can be transmitted to humans, and what are the symptoms that individuals have when COVID-19 infects them. Besides, the data reach the saturation point in terms of IIUM students' perception and attitude when all of them perceived COVID-19 as a serious problem and fear that this virus will infect them, their family, and their friends. All of them also totally agree with IIUM's action to shut down the campus during this pandemic. Lastly, the data in terms of IIUM students' behaviour also become saturated when 


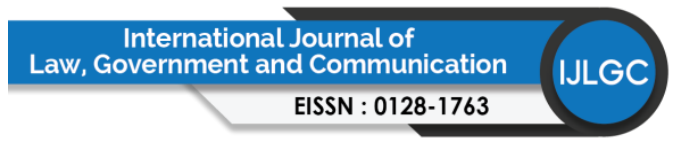

Volume 6 Issue 24 (June 2021) PP. 01-17

DOI 10.35631/IJLGC.624001

all of the respondents at least practice wearing facemask and hand sanitizers whenever they go out to public places.

Given the findings from this study, it is reasonable to conclude that future efforts should be aimed at enhancing awareness campaigns among international students. The government of Malaysia has given adequate and ample information to the Malaysians, not only via social media and traditional media such as television and radio but also via messages that Malaysian National Security Council (MKN) has spread to every registered Malaysian phone number. However, the international students that are studying in Malaysia did not get these messages, and sometimes, a lot of them stayed in their hostel room without television and radio. Moreover, international students like from Indonesia might understand Bahasa, so they can understand the information given by the Malaysian government when they listen to them through radio and television. Nevertheless, international students such as those from China and Cambodia, most of them cannot understand Bahasa. All they have is their phone and laptop, and online media is mostly their only source of information regarding COVID-19 pandemic. Thus, sometimes the information that reaches them is not enough, especially information from the Malaysian government. Hence, the regulatory body of every university in Malaysia that has international students' needs to acknowledge this situation and disperse more information or run an online awareness campaign on COVID-19 for their students, nationally and internationally.

\section{Limitations of the Study}

Specifically, this study provided new insight towards university students' awareness, attitude and practiced related to COVID-19. However, there are limitations to this project. First, the findings of the study have a limited quantity of participants. As such, more participants need to be included, not only to reach the saturated point, but to reach data richness too (Dibley, 2011). Also, this study is conducted during the pandemic outbreak, and due to the Restricted Movement Order (RMO), the researchers are not allowed to go inside the campus to search and interview the respondents face-to-face. Thus, the participants need to be reached online, and it is quite challenging since not all of the IIUM students' contact numbers can be found online.

\section{Suggestions for Future Research}

For future research, when the number of COVID-19 cases in Malaysia has slow down, and IIUM students are allowed to go back to campus and able to have face-to-face classes, future researchers should get more participants as the interviewees in the study to reach data richness.

Besides, future researchers also might want to conduct quantitative interviews and test the level of variables studied in this research which are knowledge, attitude, and behaviour. In addition, the relationship of these variables with each other also can be tested. Other variables such as the way of combating fake news also might be included.

Last but not least, this study can be extended to not only university students, but too high school students and also the labours and workers in Malaysia. This is essential because high school students, especially those who need to sit in the Sijil Pelajaran Malaysia (SPM) paper this year, are badly affected since they cannot study properly. Also, the high schooler who just finish their high school study, their intake to universities become complicated. In addition, labours and workers in Malaysia also are terribly affected by COVID-19 when many of them become 


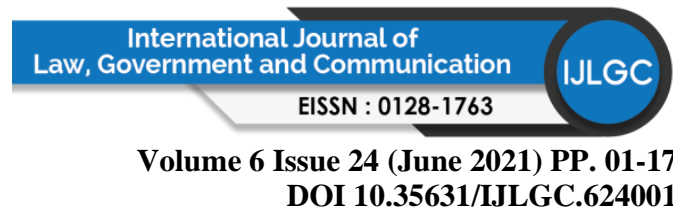

unemployed in the blink of an eye. Briefly, future studies regarding the COVID-19 pandemic should be conducted with high school students or workers in Malaysia as the target population.

\section{Biodata}

Nur Izzati Ariffin is a Master of Human Sciences in Communication graduate. She graduated from International Islamic University Malaysia (IIUM) Gombak, Selangor, Malaysia. Her research interests are in Journalism, Cultural Communication, Organizational Communication, Social Media, and Health Communication.

Siti Hajar Mohd Badrol is a Master graduate of the Department of Communication in IIUM. She graduated with a Master of Human Sciences in Communication from IIUM. Her research interests are in Social Media, Health Communication, Public Relations, and Family Communication.

Siti Aida Aliah Mohd Azlan is a master of communication student of IIUM. Her research interests are in Corporate Communication and Public Relations.

Dr. Faridah Hussain is a Senior Lecturer at the Faculty of Law, Universiti Teknologi MARA (UiTM), Shah Alam, Selangor. She obtained her Ph.D. from International Islamic University Malaysia (IIUM) specializing in Privileged Wills. Her research interests are in Probate and Administration of Estate, Civil Trial and Advocacy, Civil Procedure, Ethics of the Legal Profession, Business Law, Environmental Law, Media Law, Health Communication, and Journalism.

\section{References}

Annuar, A. (2020, February 13). IIUM postpones classes for 10 days, denies COVID-19 outbreak in campuses. Malay Mail. Retrieved March 16, 2020, from https://www.malaymail.com/news/malaysia/2020/02/13/iium-postpones-classes-for10-days-denies-COVID-19-outbreak-in-campuses/1837180

Atlas. (n.d.). Data collection - Methods in qualitative data analysis. Retrieved August 01, 2020, from https://atlasti.com/data-collection/

Berlinger, J. (2020, March 6). WHO warns governments 'this is not a drill' as coronavirus infections near 100,000 worldwide. CNN. Retrieved March 28, 2020, from https://edition.cnn.com/2020/03/06/asia/coronavirus-COVID-19-update-who-intlhnk/index.html

Chai, D. (2020, February 07). Novel Coronavirus. Retrieved March 13, 2020, from https://www.unicef.org/malaysia/stories/novel-coronavirus

Dibley, L. (2011). Analysing narrative data using McCormack's Lenses. Nurse Researcher, 18(3), 13-19. doi:10.7748/nr2011.04.18.3.13.c8458

Doyle, A. (2020, June 27). What is a semi-structured interview? Retrieved June 30, 2020, from https://www.thebalancecareers.com/what-is-a-semi-structured-interview2061632\#: :text=A\%20semi\%2Dstructured\%20interview\%20is,straightforward\%20q uestion\%20and\%20answer\%20format.

Dudovskiy, J. (n.d.). Purposive sampling. Retrieved August 01, 2020, from https://researchmethodology.net/sampling-in-primary-data-collection/purposive-sampling/

Grunig, J. E., \& Hunt, T. (1984). Managing public relations. Belmont, CA: Wadsworth / Thomson Learning. 


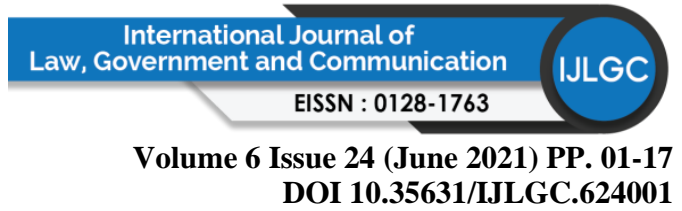

Guo, Y. R., Cau, Q. D., Hong, Z. S., Tan, Y. Y., Chen, S. D., Jin, H. J., . . Yan, Y. (2020). He origin, transmission and clinical therapies on coronavirus disease 2019 (COVID-19) outbreak - an update on the status. Military Med Res 7, (7). doi:https://doi.org/10.1186/s40779-020-00240-0

Kementerian Kesihatan Malaysia (KKM). (2020). COVID-19 Malaysia Updates. Retrieved March 20, 2020, from http://COVID-19.moh.gov.my/terkini/032020/situasi-terkini-11mac-2020

Nazario, B. (2020, August 21). Symptoms of Coronavirus: Early signs, serious symptoms and more. Retrieved August 23, 2020, from https://www.webmd.com/lung/COVID-19symptoms\#1

QuestionPro. (2020, July 13). Qualitative research: Definition, types, methods and examples. Retrieved August 01, 2020, from https://www.questionpro.com/blog/qualitativeresearch-methods/

Reuter. (2020, January 22). Thailand finds fourth China coronavirus infection. New Straits Time. $\quad$ Retrieved March 18, 2020, from https://www.nst.com.my/world/world/2020/01/558753/thailand-finds-fourth-chinacoronavirus-infection

Reynolds, M., \& Weiss, S. (2020, May 27). How coronavirus started and what happens next, explained. Wired. Retrieved June 13, 2020, from https://www.wired.co.uk/article/china-coronavirus

Schmitz, A. (2012). The Situational Theory of Publics predicts active or passive behaviour. Retrieved August 09, 2020, from https://2012books.lardbucket.org/books/publicrelations/s08-02-the-situational-theory-of-publ.html

Shuttleworth, M., \& Wilson, L. T. (2008, September 14). Qualitative research design. Retrieved July 07, 2020, from https://explorable.com/qualitative-research-design

Smith, A. (2020, May 6). What are the early symptoms of coronavirus (COVID-19)? Retrieved May 9, 2020, from https://www.medicalnewstoday.com/articles/coronavirus-earlysymptoms

Temporary Measures for Reducing the Impact of Coronavirus Disease 2019 (COVID-19) Act 2020

World Aware. (2020, March 05). Southeast Asia countries report COVID-19 Cases. Retrieved March 20, 2020, from https://www.worldaware.com/southeast-asia-countries-reportCOVID-19-cases

World Health Organization. (2020). Coronavirus. Retrieved April 30, 2020, from https://www.who.int/health-topics/coronavirus\#tab=tab_1 